\title{
LAUNCHING GEMPITA BUMIL GERAKAN MAKAN PISANG DAN JALAN PAGI TERATUR BAGI IBU HAMIL
}

\author{
Diki Retno Yuliani*1) ; Erni Juniartati1); Dyah Lustika Rahayu²); Umi \\ Rofikoh ${ }^{2) ;}$ Tuti1); Dian Rohmatika1); Uning Sulistiarini1); \\ 1)Magister Terapan Kesehatan Poltekkes Kemenkes Semarang \\ Jl. Tirtoagung; Pedalangan; Banyumanik; Semarang; Jawa Tengah; Indonesia \\ 2) Puskesmas Rawalo Dinas Kesehatan Kabupaten Banyumas \\ Jl. HM Bachroen No 369, Rawalo, Banyumas; Jawa Tengah; Indonesia
}

\begin{abstract}
Abstrak
Kematian Ibu di Kabupaten Banyumas periode Januari - Juni 2018 didominasi oleh preeklampsia berat. Pada periode yang sama Puskesmas Rawalo memiliki data rujukan preeklmapsia jauh lebih tinggi dibanding data deteksi dini risiko tinggi preeklampsia. Perjalanan penyakit preeklampsia seringkali tidak memberikan gejala tanda di awal, namun dapat memburuk dengan cepat. Oleh karenanya, diperlukan upaya preventif untuk menekan angka kejadian preeklampsia. Salah satu inovasi sebagai upaya preventif preeklampsia adalah launching GEMPITA BUMIL (gerakan makan pisang dan jalan pagi teratur bagi ibu hamil). Tujuan kegiatan ini adalah masyarakat mengerti faktor risiko, tanda bahaya dan upaya pencegahan preeklampsia serta memperkenalkan GEMPITA BUMIL yang merupakan kerjasama Puskesmas Rawalo dengan Mahasiswa Magister Terapan Kebidanan Poltekkes Kemenkes Semarang. Peserta adalah perwakilan ibu hamil masing-masing desa di Wilayah Kerja Puskesmas Rawalo, sejumlah 18 orang. Rangakaian kegiatan launching GEMPITA BUMIL meliputi penapisan faktor risiko preeklmapsia, pelaksanaan jalan pagi, makan pisang bersama dan penyuluhan. Semua ibu hamil mengikuti kegiatan dengan antusias dari awal sampai akhir. Hasil penapisan, $89 \%$ ibu hamil memiliki faktor risiko dengan rentang 1 - 5. Faktor risiko preeklampsia yang paling dominan adalah penyakit gigi di urutan pertama, nulipara di urutan kedua serta usia $>35$ tahun dan multipara yang jarak kehamilan sebelumnya $\geq 7-10$ tahun di urutan ketiga. Rekapitulasi penapisan faktor risiko preeklmapsia tersebut telah dilaporkan kepada Puskesmas Rawalo untuk di lakukan tindak lanjut. Materi yang disampaiakan dalam penyuluhan meliputi definisi preeklampsia dan superimposed preeklampsia, faktor risiko preeklampsia dan superimposed preeklampsia, tanda gejala preeklampsia, upaya pencegahan preeklapmsia, manfaat makan pisang bagi ibu hamil, manfaat jalan pagi teratur bagi ibu hamil dan kontraindikasi jalan pagi serta kapan waktu jalan pagi yang dianjurkan. GEMPITA BUMIL akan dilaksanakan di masing-masing desa di Wilayah Kerja Puskesmas Rawalo mengikuti jadwal kelas ibu hamil. Di anjurkan kepada seluruh ibu hamil untuk melaksanakan secara rutin di rumah.
\end{abstract}

Kata kunci: GEMPITA BUMIL; makan pisang; jalan pagi teratur; ibu hamil

Abstract

[LAUNCHING GEMPITA BUMIL GERAKAN MAKAN PISANG DAN JALAN PAGI TERATUR BAGI IBU HAMIL] Maternal Death in Banyumas District for the period of January June 2018 is dominated by severe preeclampsia. During the same period, Rawalo Health Center had far higher preeclampsia referral data compared to early detection data for high risk of preeclampsia. The course of preeclampsia often does not provide signs of symptoms at the beginning, but can worsen quickly. Therefore, preventive efforts are needed to reduce the incidence of preeclampsia. One of the innovations as a preventive effort for preeclampsia is the launching of BUMIL GEMPITA (movement of eating bananas

*) Correspondence author (Diki Retno Yuliani)

E-mail: dikiretnoyuliani@gmail.com and regular morning walks for pregnant women). The purpose of this activity is to understand the 
risk factors, danger signs and prevention efforts of preeclampsia and introduce GEMPITA BUMIL which is a collaboration between the Public Health Center of Rawalo and the Midwifery Applied Students of the Health Politechnic of Health Ministry Semarang. Participants were representatives of pregnant women in each village in the Rawalo Health Center Work Area, a total of 18 people.The range of GEMPITA BUMIL launching activities includes screening of risk factors for preeclampsia, morning walk, eating bananas together and counseling. All pregnant women participate enthusiastically from beginning to end. Screening results, $89 \%$ of pregnant women have risk factors in the range 1 - 5. The most dominant risk factors for preeclampsia are dental disease in the first place, nullipara in the second place and age $>35$ years and multipara with a previous pregnancy interval $\geq 7-10$ years third place. Recapitulation of screening for preeclampsia risk factors was reported to Rawalo Health Center for follow-up. The material presented in the counseling included the definition of preeclampsia and superimposed preeclampsia, risk factors for preeclampsia and superimposed preeclampsia, symptoms of preeclampsia, prevention of preeclampsia, benefits of eating bananas for pregnant women, the benefits of regular morning walks for pregnant women and contraindications to morning walks and when to walk early recommended. GEMPITA BUMIL will be held in each village in the Rawalo Health Center Work Area following the class schedule of pregnant women. Recommended for all pregnant women to carry out routinely at home.

Keywords: GEMPITA BUMIL, eating bananas, regular morning walks, pregnant women

\section{Pendahuluan}

Hipertensi dalam kehamilan (HDK) merupakan penyebab kedua angka kematian ibu (AKI) di Indonesia, meskipun bukan penyebab paling tinggi namun HDK memiliki grafik prosentase yang terus meningkat dari tahun ke tahun (KEMENKES, 2016). Salah satu HDK yang sering menjadi kondisi kegawatdaruratan adalah preeklampsia. Kasus kematian ibu di Kabupaten Banyumas periode Januari - Juni 2018 didominasi oleh preeklampsia berat (PEB) sebesar $54 \%$, dan faktor risiko preeklampsia juga menjadi nomor satu pada golongan faktor risiko III (Banyumas, Juni 2018).

Di Puskesmas Rawalo selama 5 tahun terkhir tercatat tidak ada kasus kematian ibu, namun data kasus rujukan di PONED periode Januari Juni 2018 paling banyak adalah preeklampsia, baik preeklampsia (preeklampsia ringan / PER) maupun preeklampsia dengan perburukan (PEB). Hal tersebut menunjukkan bahwa ibu hamil dengan risiko tinggi preeklampsia di wilayah Puskesmas Rawalo mendominasi seperti halnya di wilayah Kabupaten Banyumas pada umumnya.

Tingginya kasus rujukan preeklampsia di PONED Puskesmas Rawalo tidak sebanding dengan data risiko tinggi preeklampsia yang dihimpun secara berkala dari masing-masing bidan desa. Jumlah kasus rujukan periode Januari - Juni 2018 di PONED sejumlah 33 kasus dan menjadi penyebab no 1 rujukan, sedangkan data risiko tinggi preeklampsia periode Januari-Juni 2018 hanya 3 kasus, selisih yang cukup jauh dengan perbandingan $1: 11$ antara risiko tinggi yang telah terdeteksi dini dengan kasus rujukan.

Belum dapat dijelaskan apa yang menyebabkan ketimpangan tersebut, padahal upaya deteksi dini risiko tinggi yang salah satunya preeklampsia telah dilaksanakan dengan baik. Masing-masing bidan desa melaksanakan pendataan secara rutin setiap bulan terhadap semua ibu hamil di wilayahnya termasuk apa saja faktor risiko yang dimiliki dan masuk dalam kategori faktor risiko 1, 2 atau 3. Pendataan tersebut berlaku untuk semua ibu hamil, tidak hanya pada ibu hamil yang baru kunjungan pertama saja. Hasil wawancara dari beberapa bidan menyatakan bahwa ibu hamil dengan preeklampsia sering kali tidak menunjukkan kenaikan tekanan darah selama pemeriksaan antenatal care (ANC), namun tiba-tiba tekanan darah naik pada akhir trimester III atau menjelang persalinan.

Menurut sebuah kepustakaan yang ditulis oleh POGI (Perkumpulan Obstetri da Ginekologi Indonesia) menyatakan bahwa, perjalanan penyakit preeklampsia seringkali tidak memberikan gejala dan tanda yang nyata pada awalnya, namun pada suatu ketika dapat memburuk dengan cepat. Ada beberapa upaya pencegahan yang dapat dilakukan, salah satunya adalah pencegahan primer. Pencegahan primer merupakan upaya untuk mencegah terjadinya penyakit (preeklampsia). Walaupun sudah banyak penelitian dilakukan namun sayangnya belum ada satu tes pun yang memiliki sensitivitas dan spesifitas yang tinggi untuk mengetahui penyebab pasti preeklampsia dan meramalkan kejadian preeklapmsia. Oleh karena itu agar dapat dilakukan upaya pencegahan 
primer terhadap terjadinya preeklampsia, praktisi kesehatan diharapkan dapat mengidentifikasi faktor risiko preeklampsia dan kemudian mengkontrolnya (Noroyono \& dkk, 2016). Upaya preventif tersebut sangat dibutuhkan guna menekan angka kejadian preeklampsia, sehingga kematian ibu akibat preeklampsia semakin berkurang.

Selain identifikasi faktor risiko preeklampsia, upaya preventif lain yang dapat diterapkan sebagai upaya pencegahan terjadinya preeklampsia adalah dengan makan pisang dan jalan pagi teratur bagi ibu hamil. Buah pisang memiliki kandungan kalium yang tinggi, yang dapat membantu menurunkan tekanan darah. (Lestari \& Kartikasari, 2016). Sebuah penelitian melaporkan bahwa kurangnya konsumsi makanan yang tinggi kalium dapat menyebabkan peningkatan tekanan darah (sistol dan diastol) pada ibu hamil (Pujiani, Nurapriyanti, Widyawati, \& Ulfiana, 2017).

Jalan kaki di pagi hari adalah cara sederhana untuk membuat tubuh tetap bugar. Kesegaran yang didapatkan di pagi hari mulai dari udara dan lingkungan akan berdampak terhadap tubuh. Kondisi ini membuat tubuh siap melakukan berbagai aktivitas selama seharian. Penelitian menyebutkan bahwa aktivitas fisik tidak hanya memberikan manfaat bagi kesehatan jantung ibu, namun juga bermanfaat bagi jantung si janin dimana jantung si janin makin kuat dan sehat. Sebuah penelitian melaporkan bahwa ibu hamil yang melakukan jalan pagi $100 \%$ tidak mengalami preeklampsia (Nurhidayati, 2016). Ketua POGI Kabupaten Banyumas juga memberikan anjuran terkait aktivitas fisik bagi ibu hamil, yaitu ibu hamil dianjurkan untuk jalan pagi setiap hari sebagai salah satu upaya mencegah preeklampsia.

Oleh karena itu tim berkeinginan untuk membuat suatu inovasi dengan tujuan agar masyarakat lebih mengerti tentang faktor risiko, tanda bahaya dan upaya pencegahan pada preeklampsia serta mengenalkan kepada masyarakat tentang GEMPITA BUMIL sebagai salah satu upaya preventif preeklampsia. GEMPITA BUMIL merupakan kepanjangan dari, Ge (gerakan), M (makan), Pi (pi pertama pisang, pi kedua jalan pagi), Ta (teratur) dan bumil (ibu hamil).

\section{Metode}

Launching GEMPITA BUMIL merupakan kerjasama dari Puskesmas Rawalo Kabupaten Banyumas dan Mahasiswa Magister Terapan
Kebidanan Program Pascasarjana Poltekkes Kemenkes Semarang yang dilaksanakan pada hari Jum'at tanggal 10 Agustus 2018 dimulai jam 06.30 dan bertempat di halaman Puskesmas Rawalo. Peserta adalah perwakilan ibu hamil di wilayah kerja Puskesmas Rawalo yaitu dari 9 Desa. Kepanitiaan merupakan gabungan dari Puskesmas Rawalo dan Mahasiswa, sedangkan pembiayaan bersumber dari dana BOK (bantuan operasional kesehatan), BLUD (badan layanan umum daerah), kas bidan Puskesmas Rawalo dan Swadana dari mahasiswa Poltekkes Kemenkes Semarang.

Susunan acara dalam kegiatan ini meliputi pengkajian biodata dan penapisan faktor risiko preeklampsia melalui studi data di buku KIA, wawancara, pengukuran TD dan penimbangan; opening ceremony oleh Bapak Camat Kecamatan Rawalo; pelaksanaan jalan pagi bersama selama 30 menit; sambutan-sambutan dari bapak Kepala Puskesmas rawalo dan Kepala Seksi Kesehatan Keluarga dan Gizi Dinas Kesehatan Kabupaten Banyumas; makan pisang bersama; penyuluhan tentang faktor risiko, tanda bahaya dan upaya pencegahan preeklampsia dan diakhiri dengan penutup.

\section{Hasil dan Pembahasan}

Kegiatan launcing GEMPITA BUMIL dihadiri oleh 18 ibu hamil dari 9 Desa di Wilayah Kerja Puskesmas Rawalo. Semua ibu hamil terlihat antusias mengikuti rangkaian kegiatan dari awal sampai akhir, beberapa ibu hamil berinisiatif mengajukan pertanyaan selama kegiatan penyuluhan dan ketika dilaksanakan evaluasi dengan pemberian pertanyaan seputar penyuluhan, semua pertanyaan tersebut dapat terjawab dengan baik.

Penelusuran faktor risiko preeklampsia dilaksanakan dengan studi data pada buku KIA dan juga melalui wawancara langsung dengan ibu hamil serta melalui pemeriksaan TD dan BB. Total faktor risiko yang ditapis ada 18, dengan 17 faktor risiko diambil dari pedoman nasional pelayanan kedokteran diagnosis dan tata laksana preeklampsia oleh POGI tahun 2016, sedangkan 1 faktor risiko preeklampsia yaitu faktor risiko ke 14 diambil dari surat edaran pembelajaran hasil kajian AMP kematian maternal Januari-Maret 2017 yang dikeluarkan oleh Kepala Dinas Kesehatan Kabupaten Banyumas. Adapun rekapitulasi hasil pengkajiaan faktor risiko ibu hamil disajikan dalam gambar berikut. 


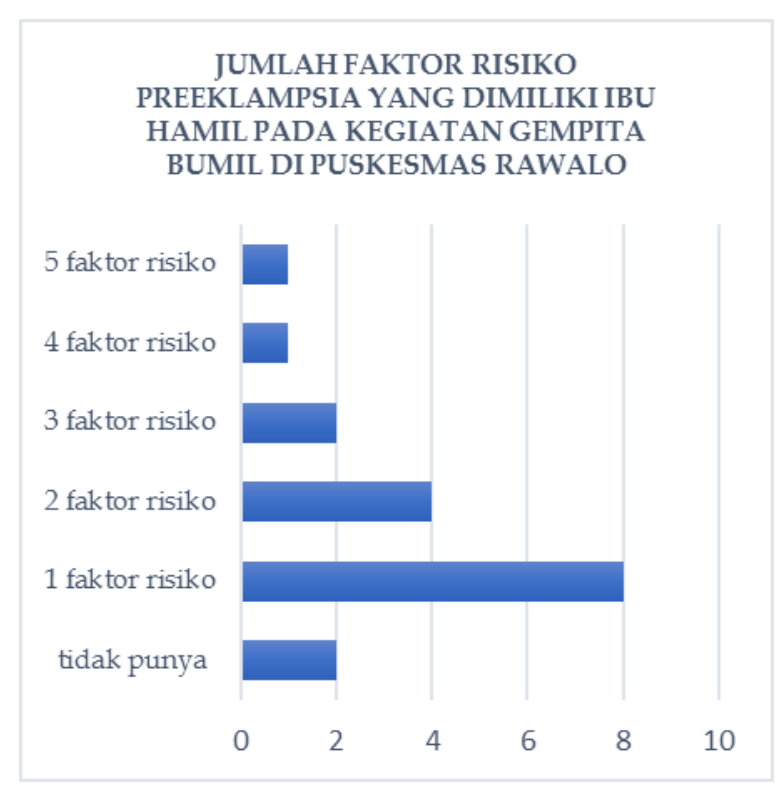

Gambar 1. Jumlah Faktor Risiko Preklampsia Yang Dimiliki Ibu Hamil

Dari gambar 1 dapat diinterpretasikan bahwa dari 18 ibu hamil mayoritas memiliki faktor risiko preeklampsia yaitu sebesar $89 \%$ (16 orang) dan yang tidak memiliki faktor risiko preeklampsia hanya $11 \%$ ( 2 orang). Banyaknya ibu hamil yang memiliki faktor risiko preeklampsia sejalan dengan data rujukan PONED Puskesmas Rawalo, dimana rujukan karena preeklmapsia adalah yang terbanyak pada periode Januari - Juni 2018. Hal tersebut memerlukan perhatian khusus dan upaya penanganan segera, misalnya dengan melaksanakan deteksi faktor risiko preeklampsia sedini mungkin, sejak kontak pertama dengan ibu hamil dengan menggunakan suatu formulir tertentu yang dapat disertakan (ditempelkan) pada buku KIA atau status pasien.

Dari ibu yang memiliki faktor risiko sebagian besar memiliki 1 faktor risiko saja yaitu sejumlah $50 \%$, dan $50 \%$ lagi memiliki faktor risiko lebih dari 1, yaitu rentang 2 - 5 faktor risiko. Banyaknya ibu hamil yang memiliki faktor risiko preeklampsia lebih dari 1 juga perlu menjadi kewaspadaan bagi Puskesmas Rawalo sebagai penanggung jawab wilayah.

Hasil pengkajian faktor risiko preeklampsia didapatkan ada $1 \mathrm{ibu}$ hamil yang memiliki faktor risiko paling banyak, yaitu 5 faktor risiko sekaligus yaitu Ny KL. Ny KL telah terdeteksi risiko tinggi preeklampsia sebelum mengikuti kegiatan GEMPITA BUMIL, mendapatkan terapi kalsium dosis tinggi $(3 \times 500 \mathrm{mg})$ dan telah mendapatkan pengawasan ketat dari bidan dan dokter spesialis, yaitu kontrol tekanan darah setiap 3 hari ke bidan dan kontrol sebulan sekali dengan dokter spesialis obtertri ginekologi di rumah sakit.

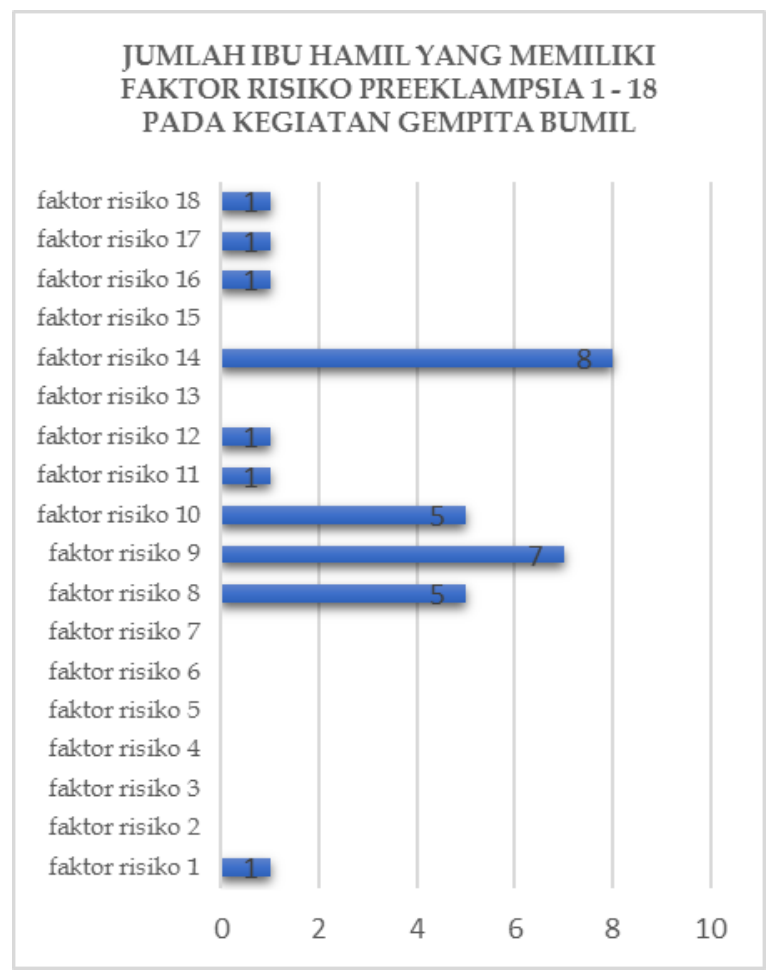

Gambar 2. Jumlah Ibu Hamil Yang Memiliki Faktor Risiko Preeklamasia 1 -18

Tabel 1. Keterangan faktor risiko preeklampsia

\begin{tabular}{|c|c|}
\hline No faktor risiko & Nama faktor risiko \\
\hline Faktor risiko 1 & Umur $>40$ tahun (risiko tinggi) \\
\hline Faktor risiko 2 & $\begin{array}{l}\text { Multipara dengan } \\
\text { preeklmapsia (risiko tinggi) }\end{array}$ \\
\hline Faktor risiko 3 & Kehamilan multiple(risiko tinggi) \\
\hline Faktor risiko 4 & $\begin{array}{l}\text { IDDM (insulin dependent diabetes } \\
\text { mellitus)(risiko tinggi) }\end{array}$ \\
\hline Faktor risiko 5 & Penyakit ginjal (risiko tinggi) \\
\hline Faktor risiko 6 & Hipertensi kronik (risiko tinggi) \\
\hline Faktor risiko 7 & $\begin{array}{l}\text { Penyakit autoimun contoh : APS } \\
\text { (sindrom antifosfolipid), systemic lupus } \\
\text { erythematous (risiko tinggi) }\end{array}$ \\
\hline Faktor risiko 8 & Umur $\geq 35$ tahun (risiko sedang) \\
\hline Faktor risiko 9 & Nulipara (risiko sedang) \\
\hline Faktor risiko 10 & $\begin{array}{l}\text { Multipara yang jarak kehamilan } \\
\text { sebelumnya } \geq 7-10 \text { tahun (risiko } \\
\text { sedang) }\end{array}$ \\
\hline Faktor risiko 11 & $\begin{array}{l}\text { Riwayat preeklampsia pada ibu atau } \\
\text { saudara perempuan (risiko sedang) }\end{array}$ \\
\hline Faktor risiko 12 & $\begin{array}{l}\text { Obesitas sebelum hamil (IMT }>30 \\
\mathrm{~kg} / \mathrm{m} 2 \text { ) (risiko sedang) }\end{array}$ \\
\hline Faktor risiko 13 & $\begin{array}{l}\text { Multipara dengan kehamilan oleh } \\
\text { pasangan Baru (primipaternitas) }\end{array}$ \\
\hline Faktor risiko 14 & Penyakit Gigi \\
\hline Faktor risiko 15 & $\begin{array}{l}\text { Kehamilan dengan inseminasi dodor } \\
\text { sperma, oosit atau embryo }\end{array}$ \\
\hline Faktor risiko 16 & $\mathrm{IMT} \geq 35$ \\
\hline Faktor risiko 17 & $\begin{array}{l}\text { Proteinuria (dipstick } \geq+1 \text { pada } 2 \text { kali } \\
\text { pemeriksaan berjarak } 6 \text { jam atau } \\
\text { secara kuantitatif } 300 \mathrm{mg} / 24 \text { jam) }\end{array}$ \\
\hline Faktor risiko 18 & Tekanan darah Diastolik $>80 \mathrm{mmHg}$ \\
\hline
\end{tabular}

Sumber : (Noroyono \& dkk, 2016) dan (Banyumas, 
Dari gambar 2 dapat diinterpretasikan bahwa faktor risiko preeklampsia yang paling dominan adalah faktor risiko 14 (penyakit gigi). Faktor risiko urutan kedua dominan adalah faktor risiko 9 (nulipara) sedangkan faktor risiko urutan ketiga dominan adalah faktor risiko 8 (umur $\geq 35$ tahun) dan faktor risiko 10 (Multipara yang jarak kehamilan sebelumnya $\geq$ 7-10 tahun). Rekapitulasi penapisan faktor risiko preeklampsia telah dilaporkan kepada Puskesmas Rawalo untuk dapat dilakukan rencana tindak lanjut.

Faktor risiko penyakit gigi menjadi faktor risiko preeklampsia terbanyak yang dialami ibu hamil peserta launching GEMPITA BUMIL, sehingga hal tersebut memerlukan perhatian khusus. Oleh karena itu mahasiswa merekomendasikan kepada Puskesmas Rawalo untuk melaksanakan pengkajian faktor risiko preeklampsia sejak kunjungan pertama ANC, kemudian diberikan pelayanan dan pemeriksaan dokter gigi, pada ibu hamil yang telah terdeteksi memiliki permasalahan gigi.

Hasil penelitian menunjukkan bahwa gigi yang bermasalah mempunyai hubungan dengan kejadian preeklampsia, salah satunya peridontitis. Hal tersebut dapat terjadi karena adanya akumulasi bakteri gram negatif yang menyebabkan pelepasan prostaglandin dan sitokin meningkat. Sitokinin yang berperan dalam peridontitis dan dapat berpengaruh terhadap preeklampsia adalah TNF- $\alpha$. Peridontitis menyebabkan peningkatan kadar TNF-a, sehingga mengakibatkan inflamasi sitemik. Pelepasan substansi sitokin dapat terjadi di tempat lain dalam tubuh bahkan pada tempat yang jauh dari rongga mulut, misalnya di plasenta. Inflamasi pada plasenta tersebut yang diduga mempunyai hubungan dengan kejadian preeklampsia (Ariningtyas, Dachlan, \& Krismariono, 2011). Sebuah penelitian menyebutkan bahwa terjadi peningkatan ekskresi TNF-a, tekanan darah dan protein urin pada tikus hamil dengan peridontitis kronis sebagai risiko preeklampsia (AMALIA, 2018).

Faktor risiko preeklampsia terbanyak kedua dalam kegiatan launching GEMPITA BUMIL adalah nulipara. Sebuah penelitian menyebutkan bahwa $62,5 \%$ ibu yang mengalami preeklampsia adalah ibu hamil primipara (Magdalena \& Historyati, 2014). Ibu hamil primigravida berisiko 4,654 kali lebih besar untuk mengalami preeklampsia dibanding multigravida (Nur \& Arifuddin, 2017). Sedangkan Duckitt melaporkan bahwa nulipara memiliki risiko hampir 3 kali lipat mengalami preeklampsia.
Pada primipara dan grandemultipara, peredaran darah dalam dinding rahim kurang, kemudian desidua atau plasenta mengeluarkan zat-zat yang menyebabkan vasospasmus dan hipertensi. Ketika semua arteriola dalam tubuh mengalami vasospasme, akan terjadi kenaikan tekanan perifer sehingga menyebabkan tekanan darah naik sebagai usaha agar oksigenasi jaringan dapat tercukupi. Secara imunologik pada kehamilan pertama terjadi pembentukan blocking antibodies terhadap antigen plasenta yang tidak sempurna. Hal tersebut menimbulkan respon imun yang tidak menguntungkan bagi kemampuan pembentukan jaringan plasenta sehingga terjadi vasokonstriksi arteri dan tekanan darah meningkat kemudian terjadi terjadi ekstravasasi (darah merembes keluar pembuluh darah) yang berakibat edema jaringan dan darah mengental (Hidayah, Sujiyatini, \& Djanah, 2014).

Faktor risiko usia $\geq 35$ tahun merupakan salah satu faktor risiko preeklampsia terbanyak di urutan ketiga. Hal tersebut sesuai dengan data risiko tinggi di Puskesmas Rawalo periode Januri- Juni 2018, dimana faktor risiko usia > 35 tahun menjadi faktor risiko I terbanyak dan juga menjadi faktor risiko terbanyak secara keseluruhan (dari faktor risiko I, II dan III) yang dimiliki oleh ibu hamil di Wilyah Kerja Puskesmas Rawalo. Hal tersebut juga sesuai dengan data rujukan PONED Puskesmas Rawalo Periode Januari - Juni 2018 dimana dari 33 kasus rujukan karena preeklampsia, 30 \% (10 kasus) diantaranya adalah ibu hamil dengan usia $>35$ tahun. Hal tersebut sesuai dengan hasil penelitian yang menyatakan bahwa mayoritas ibu hamil dengan preeklampsia berusia $>35$ tahun (37,5\%) (Handajani, 2017).

Sebuah penelitian menyebutkan bahawa ibu hamil dengan usia berisiko $(<20$ tahun atau $>35$ tahun), 7,875 kali lebih berisiko mengalami preeklampsia dibandingkan dengan ibu hamil usia reproduksi sehat (20-35 tahun) (Fatkhiyah, Kodijah, \& Masturoh, 2018). Penelitian lain menyebutkan bahwa ibu hamil dengan usia lebih dari 35 tahun mendapatkan luaran maternal yang lebih buruk yaitu preeklampsia, perdarahan antepartum dan partus dengan tindakan yang lebih banyak dibanding wanita usia reproduksi (Zubaidi \& Pramono, 2011). Seiring dengan pertambahan usia, terjadi proses degeneratif tubuh yang akan meningkatkan risiko hipertensi kronis. Dengan hipertensi kronis tersebut, ibu hamil memiliki risiko lebih besar mengalami preeklampsia (Asmana, Syahredi, \& Hilbertina, 2016). 


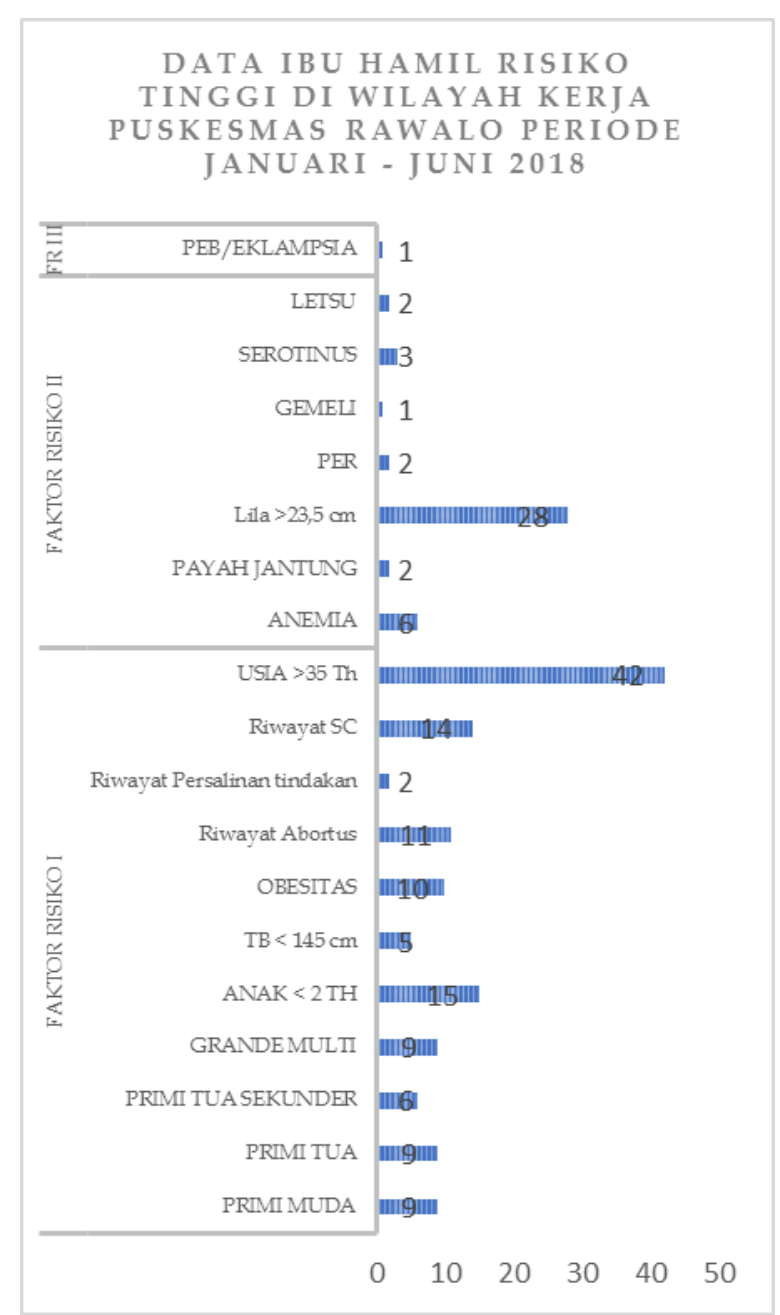

Gambar 3. Data Ibu Hamil Risiko Tinggi

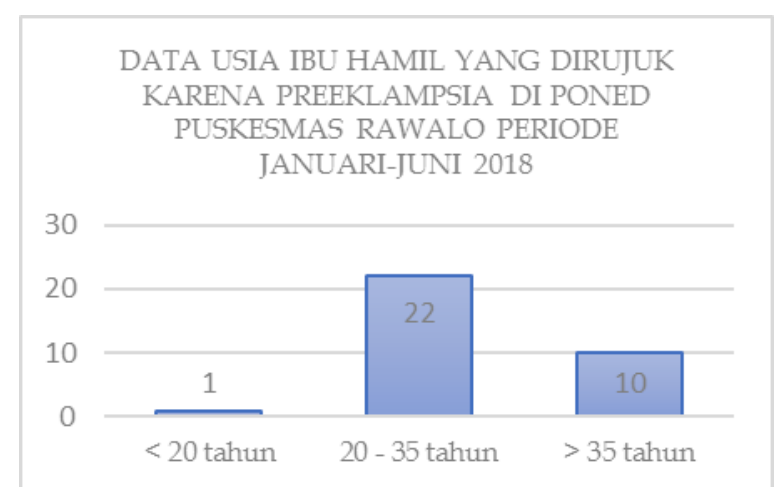

Gambar 4. Data Usia Ibu Hamil Yang Dirujuk Kaarena Preeklamasia di Poned

Selain usia > 35 tahun, faktor risiko preeklampsia terbanyak ketiga adalah multipara dengan jarak kehamilan sebelumnya $\geq 7-10$ tahun. Sebuah penelitian menyebutkan bahwa ada hubungan antara jarak kelahiran dengan kejadian preeklampsia. Jarak kelahiran 80 bulan atau lebih berisiko menderita preeklampsia 4,2 kali lebih tinggi (Nurhusna \& Wilopo, 2008). Penelitian lain menyebutkan bahwa ibu hamil multigravida dengan jarak kehamilan leih dari 5 tahun 4,49 kali lebih berisiko mengalami preeklampsia dibandingkan dengan ibu hamil multigravida dengan jarak kehamilan 1-3 tahun (KHAIRUNNISA, 2018). Studi di Norwegia menyebutkan bahwa ibu hamil multipara dengan jarak kehamilan sekarang dan sebelumnya $\geq 10$ tahun memiliki risiko preeklampsia hampir sama dengan nulipara. Robillard, dkk melaporkan bahwa risiko preeklampsia semakin meningkat sesuai dengan lamanya interval dengan kehamilan pertama ( peningkatan 1,5 kali setiap 5 tahun jarak kehamilan pertama dan kedua) (Noroyono \& dkk, 2016).

Materi yang diberikan dalam kegiatan penyuluhan meliputi definisi preeklampsia dan superimposed preeklampsia, faktor risiko preeklampsia dan superimposed preeklampsia, tanda gejala preeklampsia, upaya pencegahan preeklapmsia, manfaat makan pisang bagi ibu hamil, manfaat jalan pagi teratur bagi ibu hamil serta kontraindikasi jalan pagi serta kapan waktu jalan pagi yang dianjurkan. Faktor risiko preeklampsia telah dijelaskan pada tabel 1, sedangkan faktor risiko superimposed preeklmapsia meliputi riwayat preeklmapsia sebelumnya, penyakit ginjal kronis, merokok, obesitas, diastolik $>80 \mathrm{mmHg}$ dan sistolik $>130$ $\mathrm{mmHg}$ (Noroyono \& dkk, 2016).

Salah satu upaya preventif terhadap preeklampsia adalah dengan makan pisang dan jalan pagi teratur bagi ibu hamil. Kedua aktivitas tersebut merupakan upaya non farmaklogis yang mudah dipahami, mudah dilakukan dan membutuhkan pendanaan yang relatif murah. Sebuah penelitian melaporkan bahwa terdapat pengaruh pemberian buah pisang terhadap penurunan tekanan darah diastolik pada ibu hamil dengan hipertensi. Dimana setelah diberikan pisang kepok dengan dosis 3 kali sehari selama 7 hari, 77,8 \% ibu hamil dengan hipertensi ringan atau preeklampsia (tanpa obat-obatan) mengalami penurunan tekanan darah diastolik rata-rata $9,27 \mathrm{mmHg}$, dan dari keseluruhan responden tidak ada satu pun yang mengalami kenaikan tekanan darah diastolik (Lestari \& Kartikasari, 2016).

Penelitian menyebutkan bahwa konsumsi pisang ambon dengan dosis 1 buah pisang sehari selama 7 hari berturut-turut dapat menurunkan kenaikan tekanan sistol dan diastol wanita dewasa pada cold stres test. Prosedur kerja pada pengukuran tekanan darah adalah pengukuran sistol dan diastol pada saat fase istirahat, pada saat telapak tangan kiri dimasukkan ke dalam baskom es dengan suhu $4{ }^{\circ} \mathrm{C}$ dan setelah tangan 
kiri dikeluarkan dari baskom es. Pengukuran dilaksanakan sebelum dan sesudah konsumsi pisang. Rata-rata penurunan kenaikan tekanan darah sistol adalah $4,1 \mathrm{mmHg}$ sedangkan penurunan kenaikan tekanan darah diastol adalah 2,4 mmHg (Suherman \& Rusli, 2010).

Salah satu penyebab hipertensi adalah kurangnya kadar kalium dalam tubuh (Lestari \& Kartikasari, 2016). Hal serupa dapat terjadi pada ibu hamil dengan preeklampsia. Sebuah penelitian melaporkan bahwa ibu hamil dengan PEB memiliki kadar natrium serum dibawah normal sedangkan ibu hamil dengan eklampsia memiliki kadar natrium serum low normal. Ibu hamil dengan PEB memiliki kadar kalium serum normal, sedangkan ibu hamil dengan eklampsia memiliki kadar kalium serum low normal. Sehingga dapat disimpulkan bahwa kalium serum yang rendah lebih berperan pada pathogenesis preeklamsia - eklamsia dibandingkan dengan kadar natrium serum . dalam penelitian lain Manjareeka melaporkan bahwa pada ibu hamil dengan preeklampsia terdapat peningkatan kadar natrium dan penurunan kadar Kalium serum dibandingkan dengan ibu hamil normal (Helga, Serudji, \& Bachtiar, 2016).

Penelitian lain menyebutkan bahwa ada hubungan yang signifikan antara defisiensi kalium saat hamil dengan kejadian preeklamsia. Dimana 92,2 \% ibu hamil dengan preeklamsia memiliki kadar kalium tidak normal, dan 95,1 \% ibu hamil tanpa preeklamsia memiliki kadar kalium normal (Suryandari \& Rahayu, 2016).

Dalam journal of the American College Of Cardiology disebutkan bahwa asupan kalium sebesar $1.600 \mathrm{mg}$ per hari dapat menurunkan risiko stroke lebih dari $20 \%$. Kandungan kalium pada satu buah pisang rata-rata adalah $500 \mathrm{mg}$ (Lestari \& Kartikasari, 2016), sehingga jika sehari diberikan pisang dengan dosis 3 kali, perkiraan total asupan kalium perhari adalah $1500 \mathrm{mg}$.

Salah satu manfaat dari kalium diantaranya menormalkan irama jantung sehingga membantu peredaran oksigen ke otak. Kandungan kalium juga dapat menyebabkan pelebaran pembuluh darah, menghambat sekresi renin yang merupakan hormon yang berperan terhadap peningkatan tekanan darah, serta meningkatkan pembuangan natrium (Lestari \& Kartikasari, 2016). Dalam kegiatan launching GEMPITA BUMIL, pisang yang diberikan pada ibu hamil adalah pisang ambon dengan pertimbangan di wilayah tersebut pisang ambon lebih lazim dimakan tanpa dimasak, berbeda dengan pisang kepok yang biasanya di sajikan setelah dimasak, misalkan di goreng atau direbus.

Hipertensi terjadi tidak hanya karena kurangnya asupan kalium harian namun juga rasio asupan natrium : kalium yang kurang baik. Penelitian melaporkan bahwa ada hubungan yang antara rasio asupan natrium : kalium dengan hipertensi. Arah korelasi adalah positif, yang bermakna apabila rasio asupan natrium : kalium meningkat, maka kejadian hipertensi juga meningkat. Adapun rasio normal natrium : kalium adalah 1 : 1 . Natrium dan kalium adalah pasangan mineral yang saling melengkapi aksi satu sama lain dalam tubuh. Rasio natrium : kalium berhubungan dengan keseimbangan cairan, elektrolit, asam basa sehingga dapat berpengaruh terhadap tekanan darah. $78,95 \%$ subyek yang tidak menderita hipertensi memiliki kebiasaan sering mengkonsumsi bahan makanan tinggi kalium dan jarang mengkonsumsi bahan makanan tinggi natrium. Oleh karena itu konsumsi natrium perlu diimbangi dengan kalium. (Hendrayani \& Nugraheni, 2009). Pisang adalah salah satu buah yang memiliki kandungan tinggi kalium namun rendah natrium (Suherman \& Rusli, 2010).

Upaya preventif preeklmapsia selain makan pisang adalah dengan jalan pagi teratur. Sebuah penelitian menyebutkan bahwa 50,7 \% ibu hamil memiliki aktivitas ringan. Hasil uji statistik menyatakan bahwa ada hubungan yang bermakna antara aktivitas dengan kejadian preeklmapsia, ibu hamil dengan aktivitas ringan memiliki risiko terkena preeklampsia 16,9 kali lebih besar dibandingkan dengan ibu hamil dengan aktivitas sedang (Yusrawati, Saputra, \& Machmud, 2014).

Aktivitas fisik yang dilakukan secara kontinu dalam waktu yang panjang dapat melatih kesegaran jasmani, termasuk berjalan kaki. Jalan kaki di pagi hari adalah cara sederhana untuk membuat tubuh tetap bugar. Selain melatih kesegaran jasmani, oksigen yang dihirup dan diedarkan akan melancarkan sirkulasi darah. Efeknya pada kondisi tubuh tak cepat lelah dan lebih cepat mengembalikan tubuh pada kondisi normal, serta mengurangi stres atau depresi. Gerakan langkah kaki yang berulang-ulang mengkondisikan gelombang otak kita untuk masuk ke tahap alfa, kondisi yang membuat kita bisa merasa tenang dan nyaman.

Pada kehamilan banyak terjadi perubahan fisiologis yang membutuhkan proses adaptasi. Adaptasi pada kehamilan meliputi sistem kardiovaskular dan hemodinamik, respon janin, 
metabolisme keseimbangan asam basa, termoregulasi, respirasi dan biomekanik. Hasil penelitian memunculkan pandangan bahwa adaptasi pada ibu hamil dapat ditingkatkan dengan latihan sedang secara teratur, kecuali jika terjadi insufisiensi uteroplasenta atau gangguan yang mengancam hidup. Wanita yang aktif secara fisik, memiliki volume darah, fungsi jantung, curah jantung dan vaskularisasi yang lebih besar daripada wanita yang kurang gerak. Aktivitas fisik juga bermanfaat bagi jantung si janin yaitu menjadi semakin kuat dan sehat.

Kaitannya jalan pagi secara teratur dengan preeklampsia diungkapkan dalam sebuah hasil penelitian yang menyatakan bahwa terdapat hubungan korelasi yang kuat antara jalan pagi dengan kejadian preeklampsia pada ibu hamil. Ibu hamil yang melakukan jalan pagi $100 \%$ tidak mengalami preeklampsia, sedangkan ibu hamil yang tidak jalan pagi 27,3\% mengalami preeklampsia .

Dari 84 ibu hamil yang jalan pagi, $40 \%$ melakukan jalan pagi secara teratur, $59 \%$ jalan pagi secara berkesinambungan dan 59,6\% melaksanakan jalan pagi 20-30 menit setiap harinya. Setelah melakukan jalan pagi, 85,7 \% ibu hamil merasakan manfaatnya, 86,9 \% ibu merasa rileks dan hanya 17,9 \% ibu hamil yang merasakan ketidaknyamanan dan 36,9 \% ibu pernah merasa kelelahan, pening, mual dsb, namun mayoritas ibu tidak merasakan hal tersebut.

Dr. Kenneth Cooper, sesepuh dari gerakan kebugaran yang didukung oleh para peneliti lainnya, berpendapat bahwa tubuh ini tampaknya akan memberikan tanggapan yang baik terhadap gerak badan seperti jalan pagi, empat atau lima hari per minggu dengan lama waktu gerak badan 20-30 menit. Gerak badan seperti itu akan memberikan kemanfaatan pada psikologis, pernafasan-jantung dan manfaat pada penyakit jantung (Nurhidayati, 2016).

Hal serupa juga disampaiakan oleh ketua POGI Kabupaten Banyumas dr Adi Setiawan, SpOG, K.FER, yaitu suatu anjuran sebagai salah satu upaya mencegah preeklampsia adalah dengan jalan pagi setiap hari dengan durasi 30 menit dan minimal 5 hari dalam seminggu (total 150 menit / minggu) serta dilaksanakan sebelum jam 09.00 pagi.

Adapun kontraindikasi jalan pagi selama kehamilan adalah hipertensi akibat kehamilan dan preeklampsia, ketuban pecah dini, persalinan prematur pada kehanilan sebelumnya atau terakhir, inkompetensia serviks, pendarahan persisten pada trisemester kedua sampai ketiga serta retardasi pertumbuhan intrauterine (Nurhidayati, 2016).

Mengingat besarnya manfaat dari makan pisang dan jalan pagi teratur bagi ibu hamil, oleh karena itu kegiatan GEMPITA BUMIL akan dilanjutkan yaitu dilaksanakan di masing-masing desa di Wilayah Kerja Puskesmas Rawalo mengikuti jadwal kegiatan kelas ibu hamil. Kepada seluruh ibu hamil di anjurkan untuk melaksanakan makan pisang dan jalan pagi teratur secara rutin di rumah sebagai upaya untuk menekan angka kejadian preeklampsia di Wilayah Kerja Puskesmas Rawalo. Makan pisang dan jalan pagi belum bisa dipercaya sebagai upaya preventif preeklampsia jika hanya dilakukan sekali saja atau beberapa kali yang tidak teratur.

\section{Simpulan dan Saran}

Semua ibu hamil mengikuti kegiatan dengan antusias dari awal sampai akhir. Hasil penapisan, $89 \%$ ibu hamil memiliki faktor risiko dengan rentang $1-5$. Faktor risiko preeklampsia yang paling dominan adalah penyakit gigi di urutan pertama, nulipara di urutan kedua serta usia > 35 tahun dan multipara yang jarak kehamilan sebelumnya $\geq 7-10$ tahun di urutan ketiga. Rekapitulasi penapisan faktor risiko preeklmapsia tersebut telah dilaporkan kepada Puskesmas Rawalo untuk di lakukan tindak lanjut. GEMPITA BUMIL akan dilaksanakan di masing-masing desa di Wilayah Kerja Puskesmas Rawalo mengikuti jadwal kelas ibu hamil. Seluruh ibu hamil di anjurkan untuk melaksanakan makan pisang dan jalan pagi teratur secara rutin di rumah.

Diperlukan penelitian untuk menggali lebih dalam kemanfaatan dari makan pisang dan jalan pagi teratur sebagai upaya preventif preeklampsia.

\section{Ucapan Terima Kasih}

Ucapan terimakasih kami sampaikan kepada Hendro Harjito, Angger Warastri, Sunarti, Nurul Faoziah, Kusmiyati, Sri Handayani, Ananti Setya Primawati Putri, Riza Umami, Tri Endah Widi Lestari, Tiara Widiatami, Lieni Lestari, yang telah memberikan kontribusi kepada tim dalam pelaksanaan kegiatan launching GEMPITA BUMIL di wilayah kerja Puskesmas Rawalo Kabupaten Banyumas. 


\section{Daftar Pustaka}

Amalia, P. E. (2018). Peningkatan Ekspresi Il-6, Tekanan Darah, Dan Proteinuria Pada Tikus Hamil Dengan Periodontitis Kronis Sebagai Risiko Preeklampsia (Penelitian In Vivo Pada Pregnant Wistar Rat). (Skripsi), Universitas Airlangga.

Ariningtyas, N. D., Dachlan, E. G., \& Krismariono, A. (2011). Perbandingan Kadar Tnf-Dan Mikroba Patogen Periodontal Pada Ibu Hamil Normal, Hamil Dengan Periodontitis, Dan Preeklampsia Berat Tipe Lambat. Majalah Obstetri Dan Ginekologi, 19(3), 121-127.

Asmana, S. K., Syahredi, S., \& Hilbertina, N. (2016). Hubungan Usia Dan Paritas Dengan Kejadian Preeklampsia Berat Di Rumah Sakit Achmad Mochtar Bukittinggi Tahun 2012-2013. Jurnal Kesehatan Andalas, 5(3), 640-646.

Banyumas, D. K. K. (2017). Surat Edaran Pembelajaran Hasil Kajian Amp Kematian Maternal Jan-Maret 2017. Banyumas: Kepala Dinas Kesehatan Kabupaten Banyumas.

Banyumas, D. K. K. (Juni 2018). Laporan Kesehatan Ibu, Anak Dan Gizi Masyarakat Kabupaten Banyumas. Banyumas.

Fatkhiyah, N., Kodijah, K., \& Masturoh, M. (2018). Determinan Maternal Kejadian Preeklampsia: Studi Kasus Di Kabupaten Tegal, Jawa Tengah. Jurnal Keperawatan Soedirman, 11(1), 53-61.

Handajani, S. D. (2017). Gambaran Faktor Predisposisi Preeklampsia Ibu Hamil Di Rsab Soerya, Sidoarjo. Journal Infokes Stikes Insan Unggul Surabaya, 9(1), 57-60.

Helga, H., Serudji, J., \& Bachtiar, H. (2016). Perbedaan Rerata Rasio Kalsium Magnesium Dan Rerata Rasio Natrium Kalium Serum (Difference In Mean Levels Of Calcium Magnesium Ratio And Sodium Potassium Ratio Of Maternal Serum Between Severe Preeclampsia And Eclampsia). Obgyn Emas, 1(21), 19-24.

Hendrayani, C., \& Nugraheni, S. A. (2009). Hubungan Rasio Asupan Natrium: Kalium Dengan Kejadian Hipertensi Pada Wanita Usia 25-45 Tahun Di Komplek Perhubungan Surabaya. (Thesis), Program Studi Ilmu Gizi.
Hidayah, F. N., Sujiyatini, \& Djanah, N. (2014). Faktor Risiko Paritas Terhadap Kejadian Preeklampsia-Eklampsia Pada Ibu Bersalin. Jurnal Kesehatan Ibu Dan Anak, 6(2), 35-41.

Kemenkes. (2016). Profil Kesehatan Indonesia Tahun 2015. Jakarta: Kemenkes Ri.

Khairunnisa, F. (2018). Hubungan Antara Jarak Waktu Kehamilan Dengan Kejadian Preeklampsia Pada Ibu Hamil Multigravida Di Rsud Moewardi Surakarta. (Skripsi ), Universitas Sebelas Maret.

Lestari, D., \& Kartikasari, R. I. (2016). Efektifitas Buah Pisang Untuk Menurunan Tekanan Darah Diastolik Pada Ibu Hamil Hipertensi. Surya, 8(2), 18-22.

Magdalena, M., \& Historyati, D. (2014). Gambaran Faktor Penyebab Preeklampsia Pada Kehamilan Di Wilayah Kerja Puskesmas Tembelang Jombang.

Noroyono, W., \& Dkk. (2016). Pedoman Nasional Pelayanan Kedokteran Diagnosis Dan Tata Laksana Pre-Eklamsia. Jakarta: Pogi.

Nur, A. F., \& Arifuddin, A. (2017). Faktor Risiko Kejadian Preeklampsia Pada Ibu Hamil Di Rsu Anutapura Kota Palu. Healthy Tadulako, 3(2), 69-75.

Nurhidayati, E. (2016). Hubungan Jalan Pagi Dengan Pre-Eklampsia Pada Ibu Hamil Di Wilayah Puskesmas Moncek Tengah Kecamatan Lenteng Kabupaten Sumenep Tahun 2013. Wiraraja Medika, 6(1), 9-21.

Nurhusna, \& Wilopo, S. A. (2008). Hubungan Jarak Kelahiran Dengan Kejadian Preeklampsia Di Rsup Dr. Sardjito Yogyakarta. (Thesis), Universitas Gadjah Mada.

Pujiani, I., Nurapriyanti, I., Widyawati, M. N., \& Ulfiana, E. (2017). Effect Of Ambon Banana Consumption To Decrease Blood Pressure In Pregnant Woman With Preeclamps. Paper Presented At The Proceedings Of The International Conference On Applied Science And Health.

Suherman, J., \& Rusli, M. (2010). Effect Of" Pisang Ambon"(Musa Acuminata Coola) On Adult Female Blood Pressure On Cold Stress Test. Jurnal Medika Planta, 1(2), 21-26.

Suryandari, A. E., \& Rahayu, L. D. P. (2016). Pengaruh Defisiensi Kalium Saat 
Dengan Kejadian Preeklamsia Di Rsu Harapan Ibu Purbalingga Tahun 2013. Involusi Jurnal Ilmu Kebidanan (Journal Of Midwifery Science), 3(6).

Yusrawati, Y., Saputra, N. P. K., \& Machmud, R. (2014). Faktor Resiko Individual Pada
Preeklampsia Pada Rsup Dr M Djamil Padang. Obgin Emas, 1(15), 15-21.

Zubaidi, R. F., \& Pramono, B. A. (2011). Perbandingan Luaran Maternal Dan Perinatal Ibu Usia Tua Dengan Usia Reproduksi. (Skripsi ), Faculty Of Medicine. 